بر آورد بيلان آبى در حوضههاى منتهى به خليجفارس با استفاده از مدل نيمهتوزيعى SWAT مجيد حسينى، محمد غفورى، زينب مكاريان و محمود رضا طباطبايى'

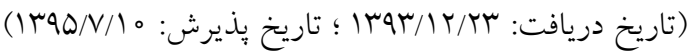

DOI: 10.18869/acadpub.jstnar.20.78.183

حكيد:

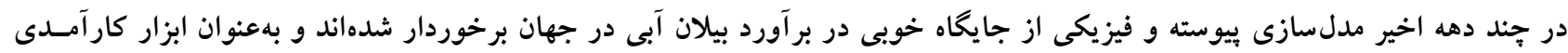

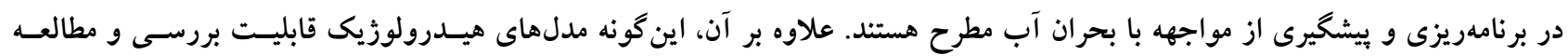

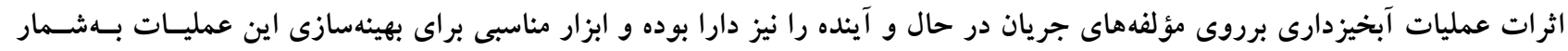

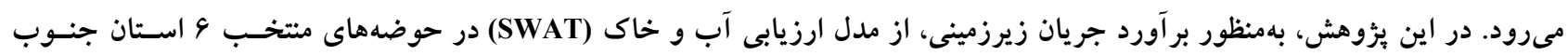

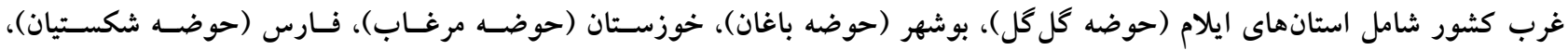

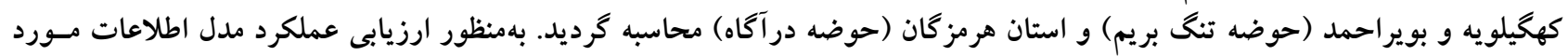

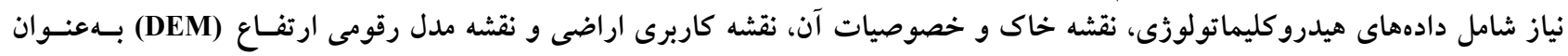

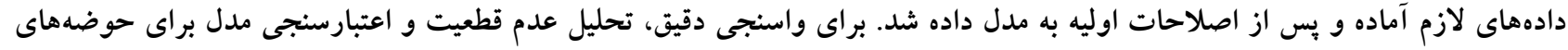

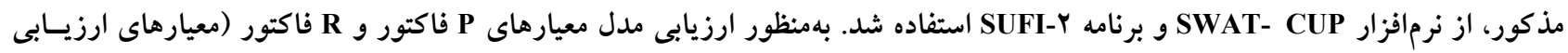

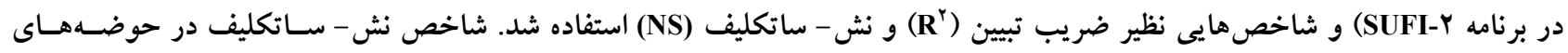

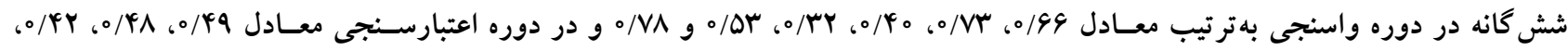

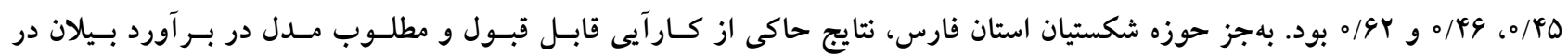
حوضههاى مورد مطالعه است.

وازههاى كليدى: بيلان آبى، حوضههاى جنوب، خليج فارس، SWAT

ا بزئوهشكده حفاظت خاك و آبخيزدارى، سازمان تحقيقات، آموزش و ترويج كشاورزى، تهران، ايران

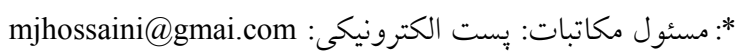


(GIS) اطلاعات در مورد حوضههاى وسيع وجود ندارد.

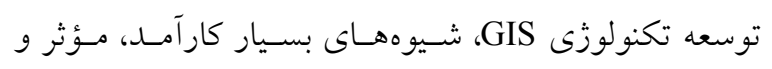

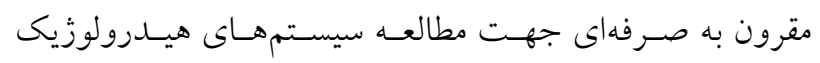

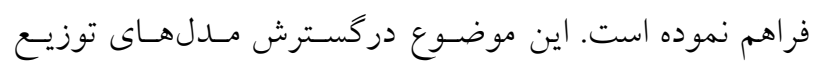

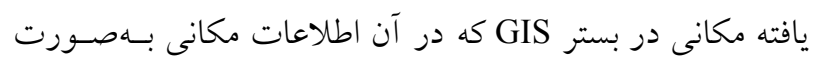

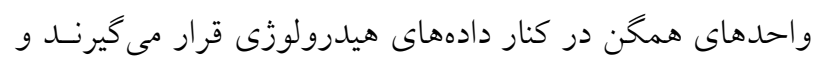

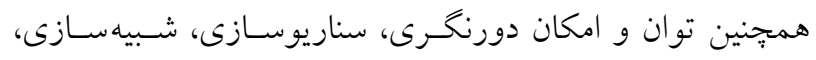

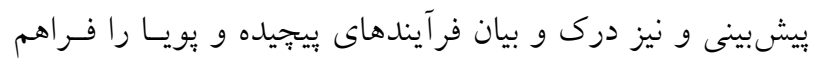
مىنمايند، سهم بهسز اييى دارد (T). اندازهيرى اجزاى بيلان آب در فاصلههاى زمانى مورد نيـاز بهاز

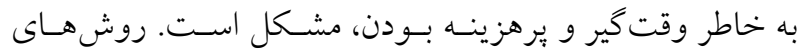

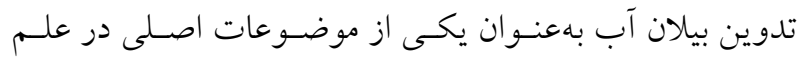

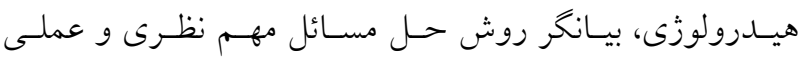

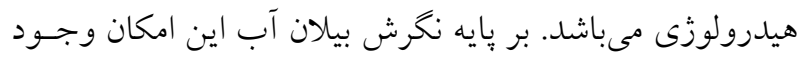

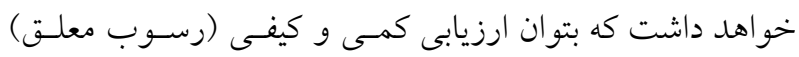

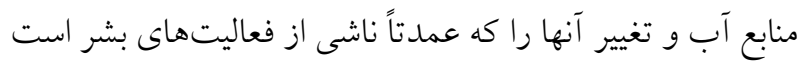

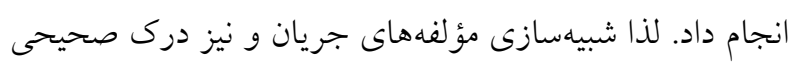

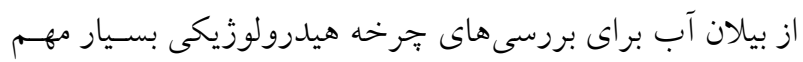

حسينى (9) با بررسى مزيت ها و معايب تعداد يـانزده مــدل

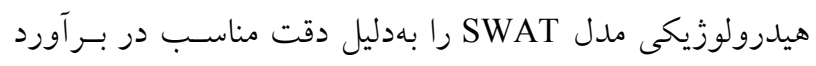

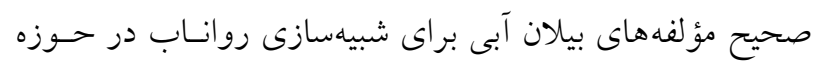

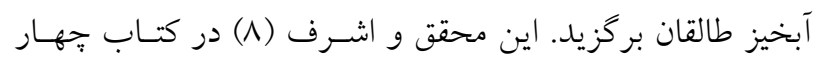

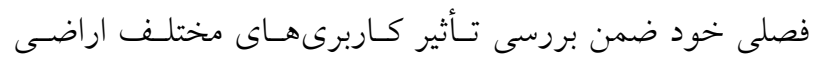

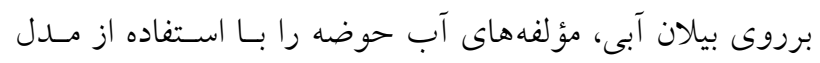

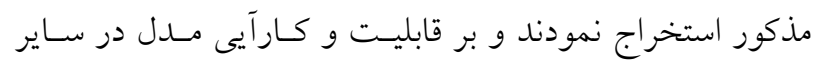
حوزههاى آبخيز كشور تأكيد داشتند. غفورى و همكاران مدلهاى هيدرولوزيكى را ابزار مفيـدى آحسئ براى بيشبينى و شبيهسازى مؤلفههاى جريان به حساب مي مئي آيند

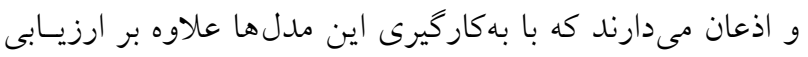

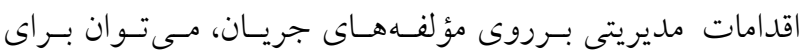

محدوديت منابع آب و افزايش نياز به آب كـه ناشسى از افـزايش

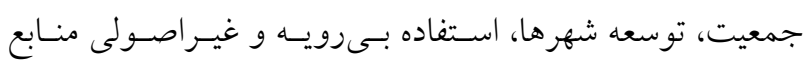

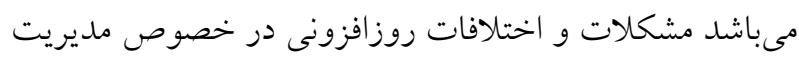

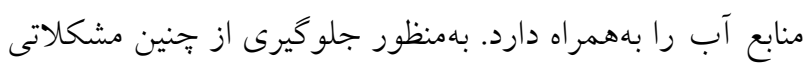

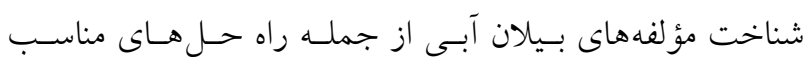

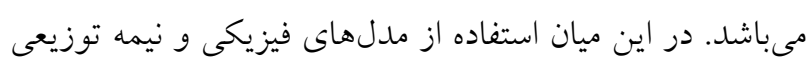

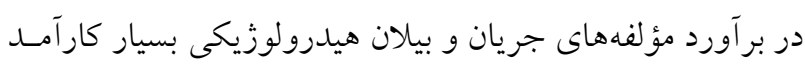

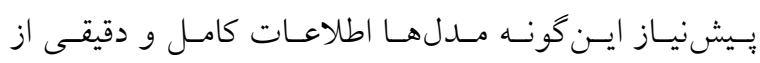

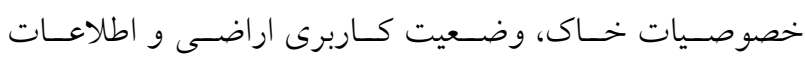
هيدروكليماتولوزى منطقه است ليكن خروجى هـات مطاى مطلـوبى از

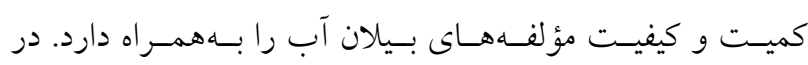

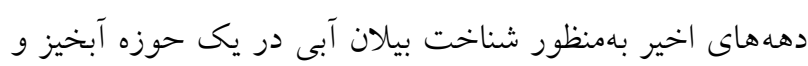

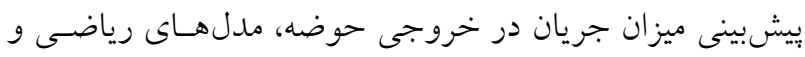

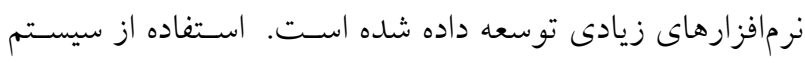

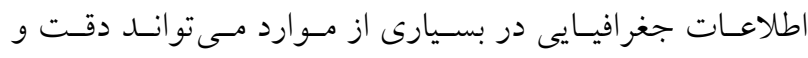

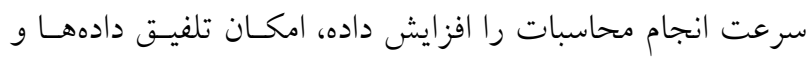

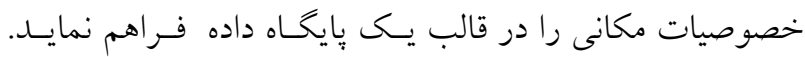

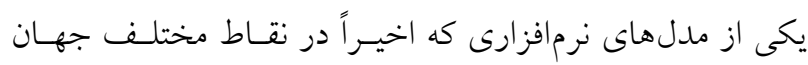

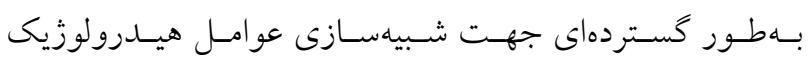

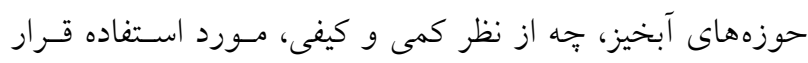

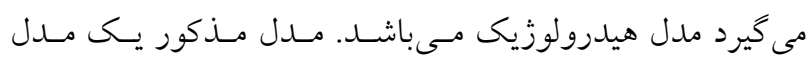

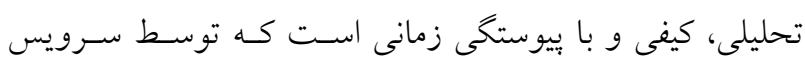

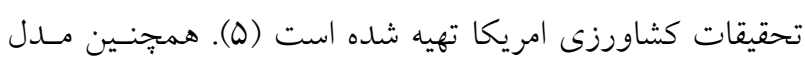
فوق يك مدل نيمهتوزيعى بوده كه براى شبيهسازى حوزه آبخيز

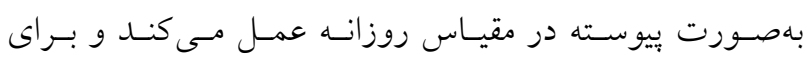

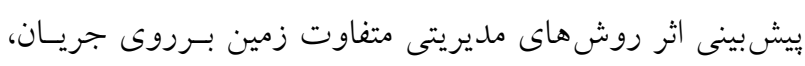

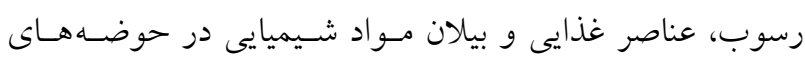

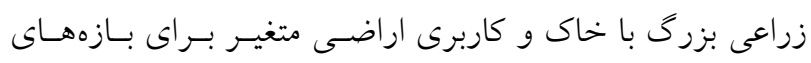

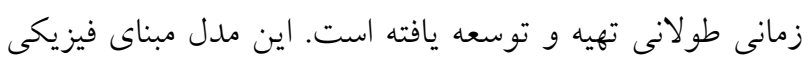

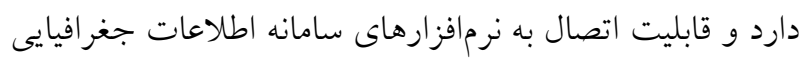




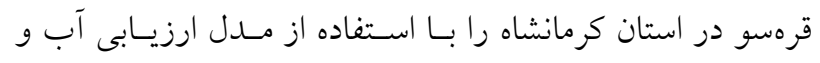

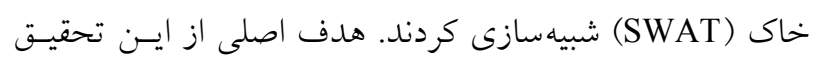

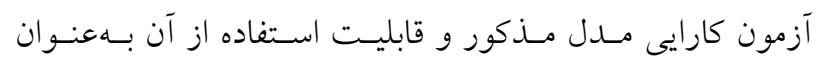

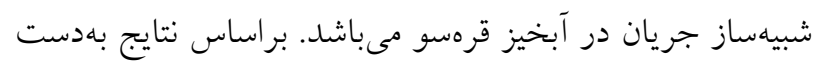

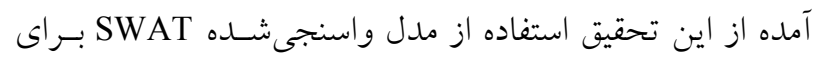

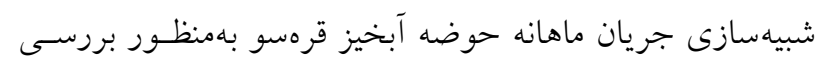

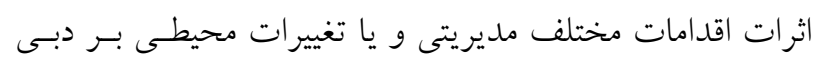
جريان توصيه مىشود.

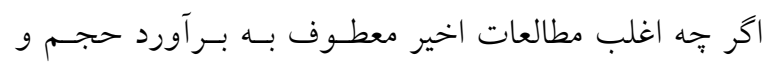

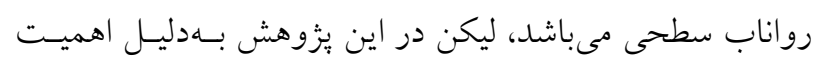

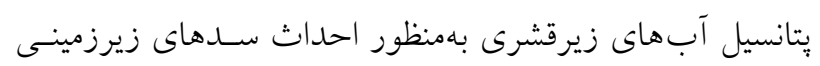

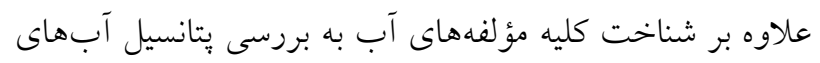

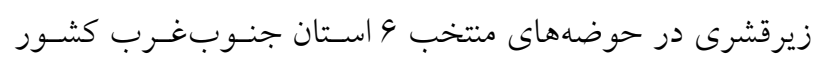

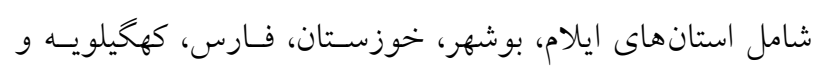
بو ير احمد و هرمز كان مورد مطالعه يرداخته شد.

\section{مواد و روشها منطقه مورد مطالعه}

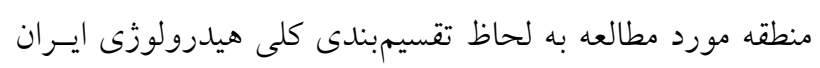

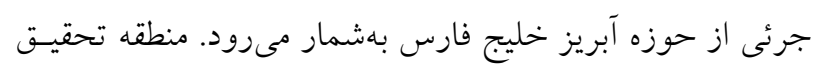

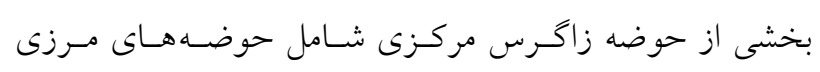

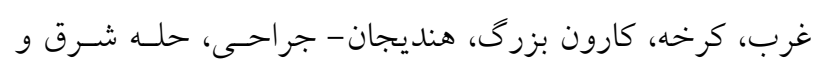

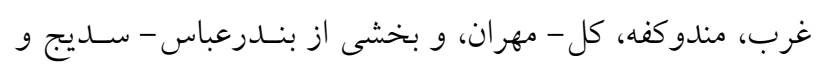

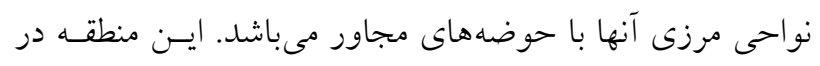

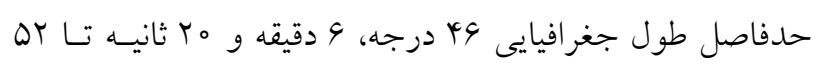

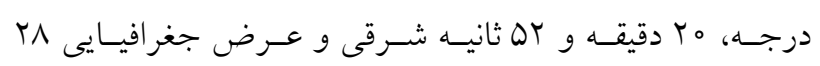

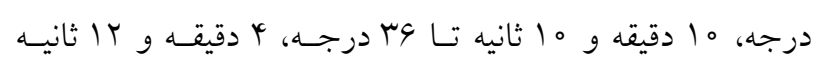

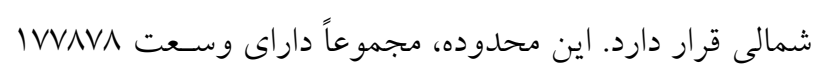

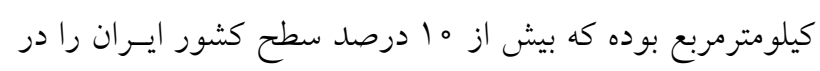
بر مى كيرد (شكل (1). با توجه به بـ شماربودن اطلاعات ورودى، بر براى انجـام ايسن

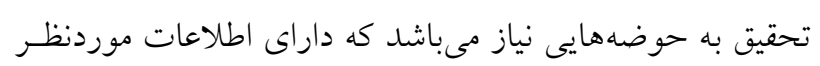

بهينهسازى عمليات كشاورزى در منطقه غير اشباع خـاك استفاده

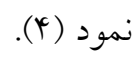

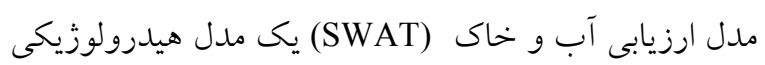

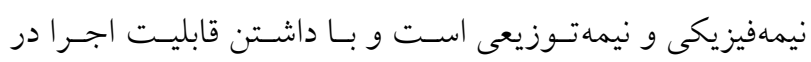

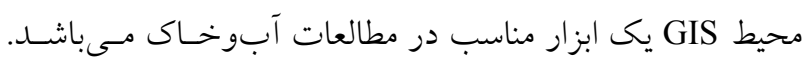

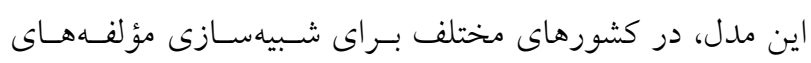

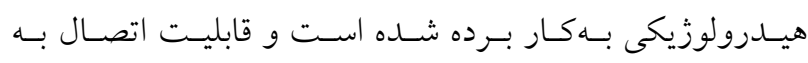

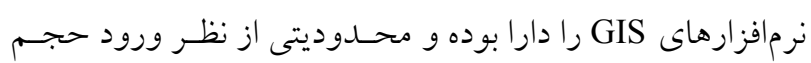
وسيعى از اطلاعات در مورد حوضههاى وسيع وجود ندارد (9). توانايى مدل در شبيهسازى فرآيندهاى هيدرولوزيكى بيجيديده

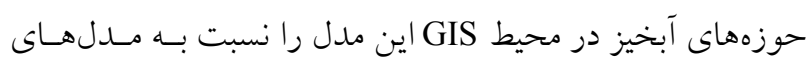

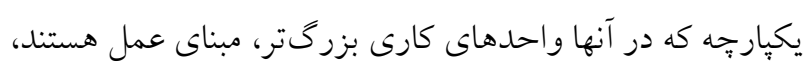
متمايز ساخته است (1). در تحقيق مذكور بهمنظور بررسى بيلان

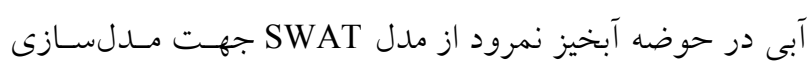
هيدرولوزيكى حوضه استفاده شده است.

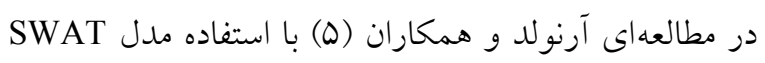

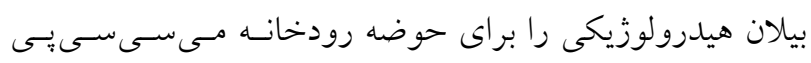

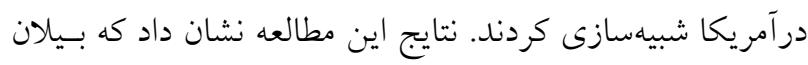

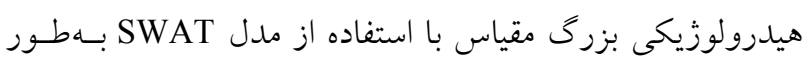

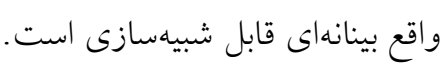

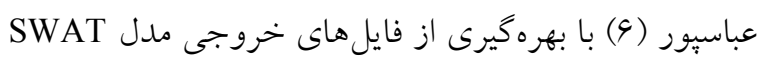

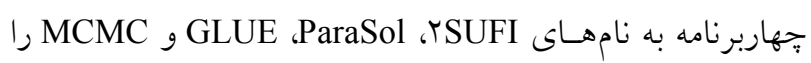

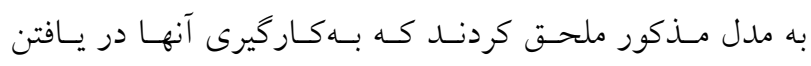

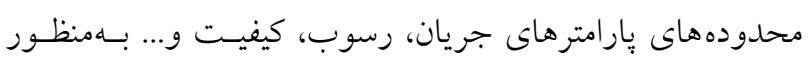
واسنجى مدل بسيار مؤثر مىباشد.

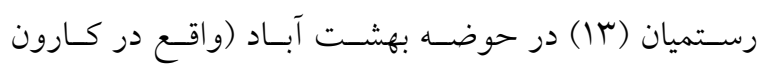

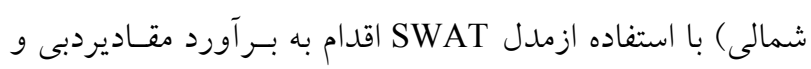

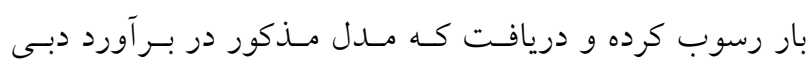

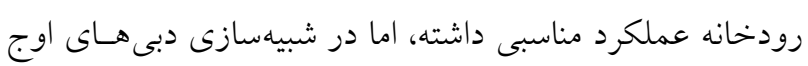

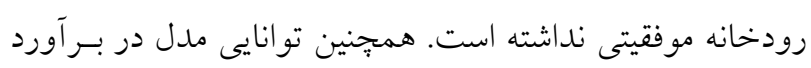
بار رسوب را در حد متوسط ارزيابى نمود.

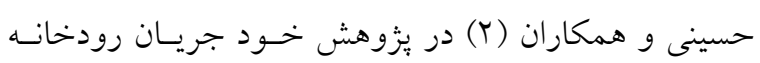


جدول ا. مشخصات حوضههاى مطالعاتى

\begin{tabular}{|c|c|c|c|c|c|c|}
\hline (كسلومترمربع) حوزه & ارتفاع ايستگاه & نام رودخانه اصلى & ايستكاه هيدرومترى & نام حوزه & استان & رديف \\
\hline r/9/NGT & 1100 & كل & سرجوى كل گل & سرجوى كَل & ايلام & 1 \\
\hline rar/qOr & 10 & باغان & باغان & باغان & بوشهر & r \\
\hline $9 \vee 9 / Y_{0} \circ$ & eVA & مرغاب جلو گير & مرغاب & مرغاب & خوزستان & r \\
\hline $9 \mid r / r \circ r$ & vit & شور & شكستيان & شكستيان & فارس & $r$ \\
\hline Vag/NA1 & VANT & شيو & تنغ بريم & تنغ بريم & كهخيلويه وبويراحمد & 0 \\
\hline YMQY $/ / 9$ & 1109 & درآكاه-كنج & درآكاه & درآكاه & هرمز كان & 9 \\
\hline
\end{tabular}

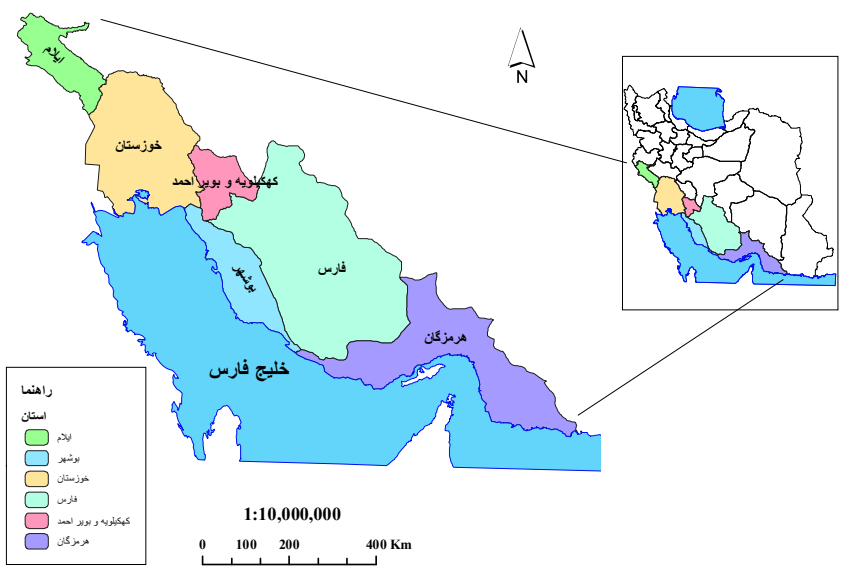

شكل ا. گُستره كلى مناطق مورد مطالعه

از قبيل بارش روزانه و دبى اندازهكيرىشـده و سـاير اطلاعـات انتخاب ايستخاههاى هيدرومترى مناسب، با بازديـدهاى ميـدانى،

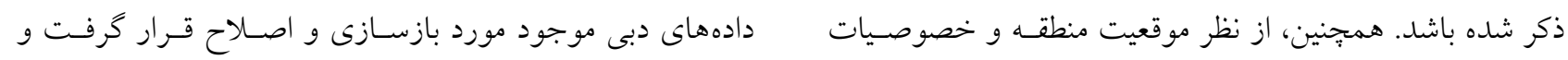

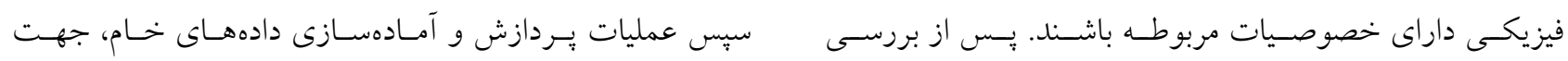

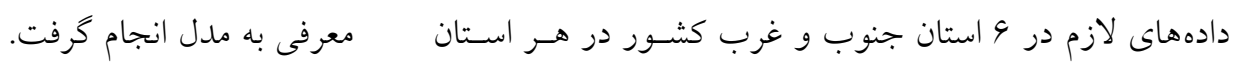

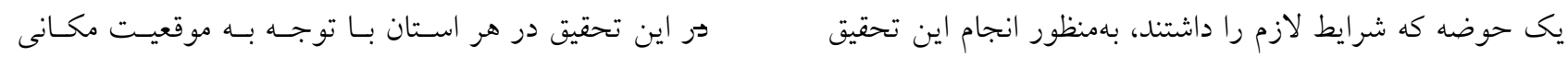

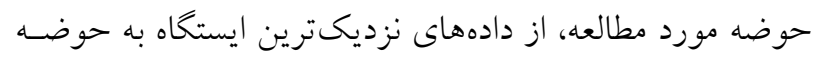

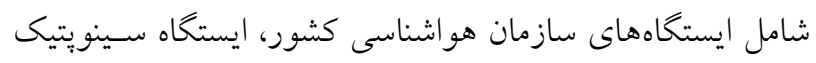

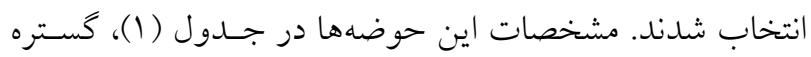

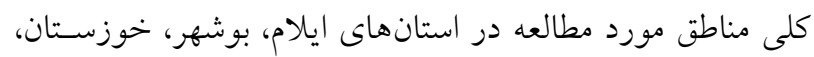

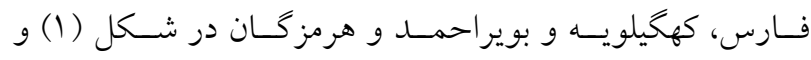
شده است. در مجموع در منطقه مورد نظر تعـداد وسا ايستخكاه تبخير سنجى و TYV ايستخاه بارانسنجى فعال موجود است. موقعيت حوضههـاى منتخـب اسـتانى در شـكل (Y) نشـان داده

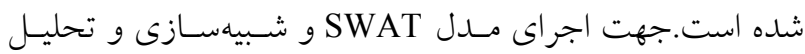

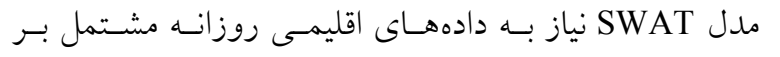
يتانسيل هاى زيرسطحى، ابتدا دادهاى ايستكاههاى تبخير سنجى بارندگى، دما، رطوبت نسبى، باد و تابش خورشيدى مىباشد. بـا

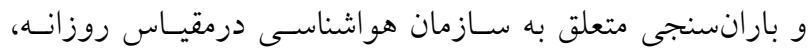

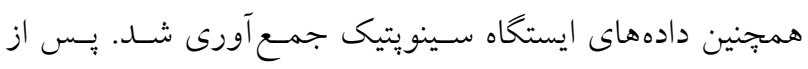




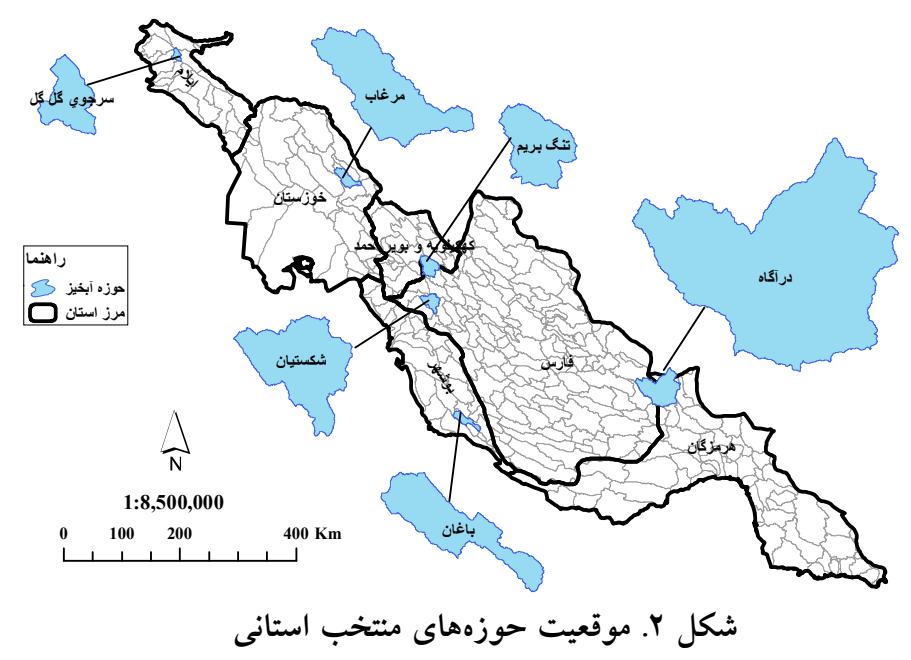

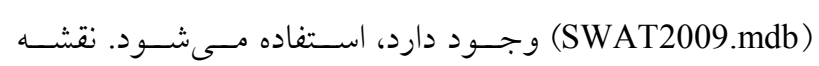
خاكشناسى مورد استفاده در اين تحقيق نيز، نقشه جهانى خاى فائو مى باشد. شكل (Y) نقشههاى خاكشناسى حوضههاى مورد مطالعه را نشان مى دهند. با توجه به زياد بودن تعداد بارامترهـاى مــل، بـراى انجــام

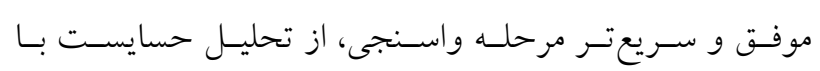

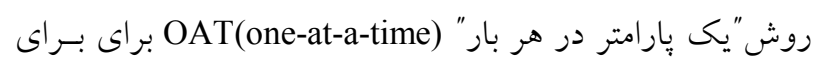

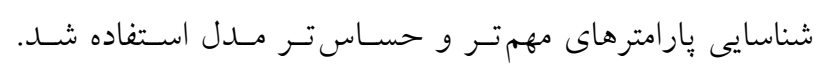

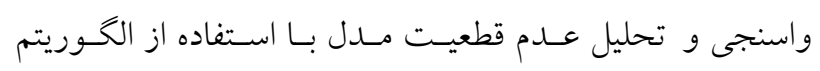
SUFIY (Sequential Uncertainty Fittingr) و براساس دادههاى جريان رودخانههاى مربوطـه واسـنجى، (V) اعتبارسنجى و سيس مورد ارزيابى آمارى قرار كرفت.

\section{نتايج و بحث}

يس از اجراى مدل SWAT خروجى هاى مدل شامل: مؤلفههاى

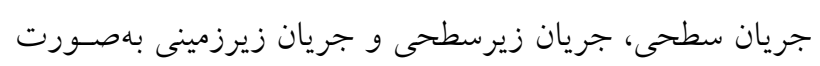
فايل متنى حاوى اطلاعات بهدست آمد. بررسى و مقايسه اوليـه نتايج نشان داد كه، مهمترين خطاهاى نتايج عبارتند از بالابـودن

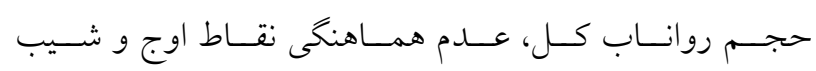

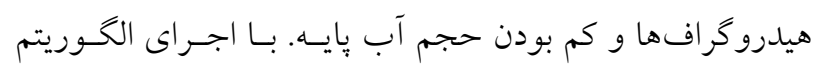

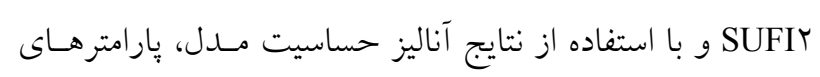
حساس براى هر حوضه بهطور جداكانـه شناسـايى شـد. نتـايج
توجه بـه محدوديتها و نقصدهـاى موجـود، بـراى بارنـدگى از

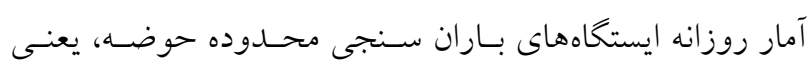

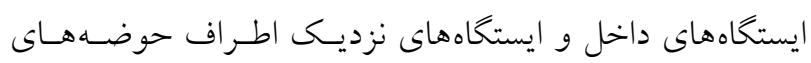
انتخابى جهت انجـام ايسن تحقيـق اسـتفاده شـده اسـت. تعـداد ايستخاه هاى مورد استفاده براى هر منطقه مطالعاتى متفاوت بوده

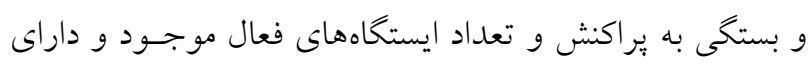
آمـار مناسـب آن اسـتان دارد. دادههــاى بــاران از مب ايسـتخاه بارانسنجى و دادههـاى درجـه حـــارت روزانـه از با ايسـتخاه

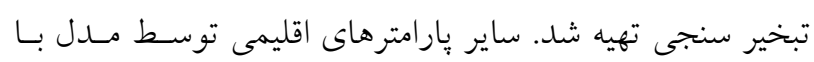

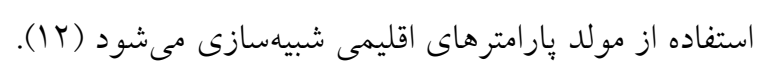
در اين تحقيق اطلاعات لازم براى ايسن محاسـبات از مــل رقومى ارتفاع رادارى يا SRTM براى زيرحوضههـاى مطالعـاتى استفاده گرديده است. كاربرى اراضى حوضههـاى مطالعـاتى در شكل (r) نشان داده شده است. برطبق اين نقشه انسواع كـاربرى

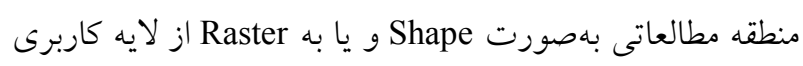

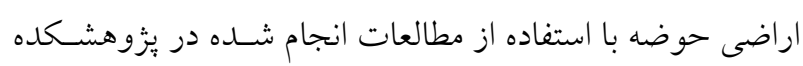
حفاظـت خـاك و آبخيـزدارى كشـور تهيـهـ شــده اسـت. طبـق كزارشهاى موجود، اين نقشه از تصوير ماهوارهاى لندست سال

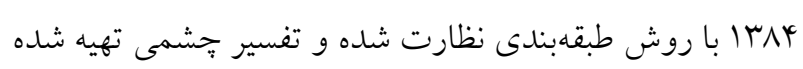
در اكثر مناطق از نقشه جهانى خاك كه توسط فائو بــا دقـت 1:1000000 

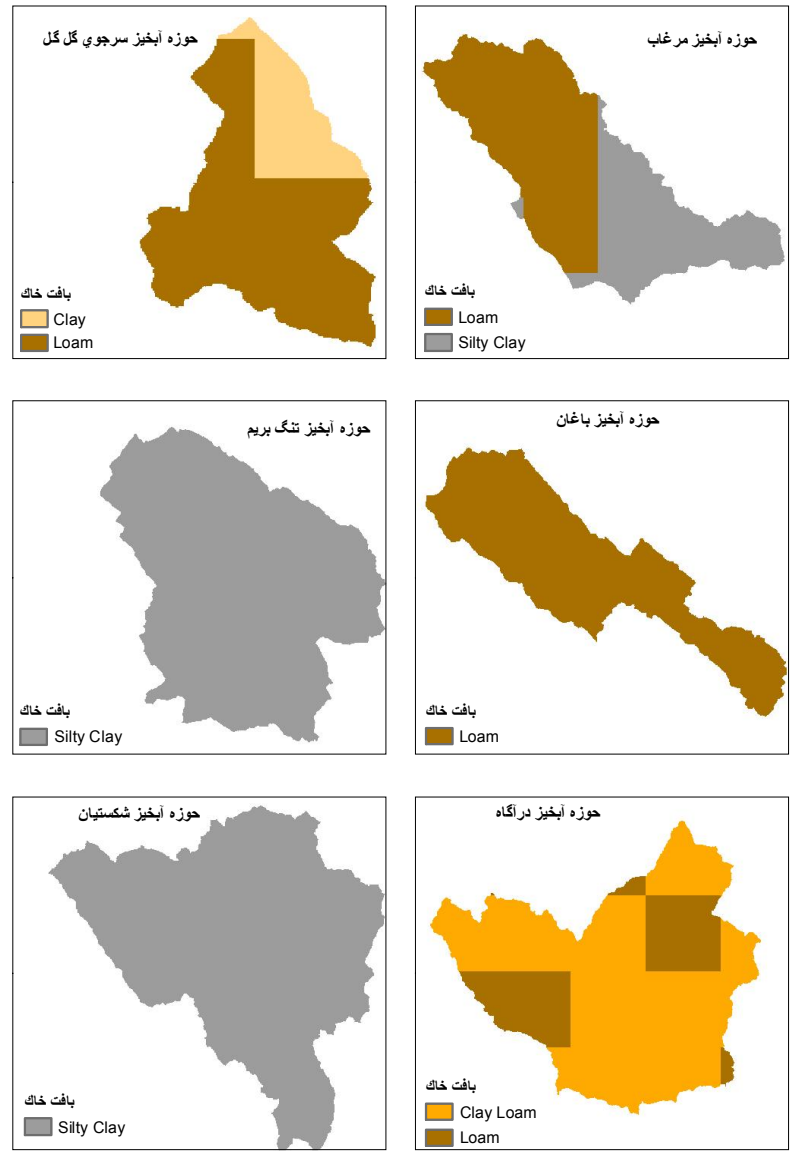

شكل f. نقشه خاكشناسى در حوضههاى مورد مطالعه

ضـريب كـارآيى نسش - سـاتكليف (NS function) و ضـريب

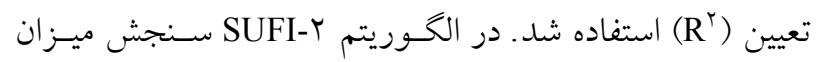
عدم قطعيت در مدلسازى شـامل عـدم قطعيـت در ورودىهـا

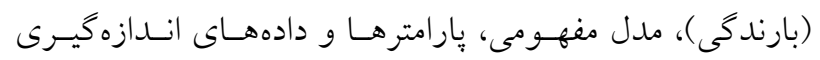
شده بوده و توسط معيار P-factor ارزيابى مى شـود كـه بيـانكر درصد دادههاى اندازه گيرى شده درون بانـد عـدم قطعيـت هو 9 درصـد (PPU90) اسـت. فـاكتور P كـه نشـان دهنـده درصـد حضور دادههاى مشاهداتى در محدوده عدم قطعيت ه9 درصـد است, اغلب PPU9D ناميده مىشـود. محسدوده فـاكتور P بـين صفر تا يك بوده و هر جِقدر عـدد بـهدسـت آمـده بـراى ايسن فاكتور به عدد يكى نزديكتر باشـد، نشـاندهنـده تطـابق بهتـر دادههاى شبيهسازى شده با دادههاى مشاهداتى يا انـدازهذيـرى

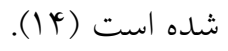

فاكتور R نشاندهنـده ضـخامت بهنـاى بانــ عــدم قطعيـت
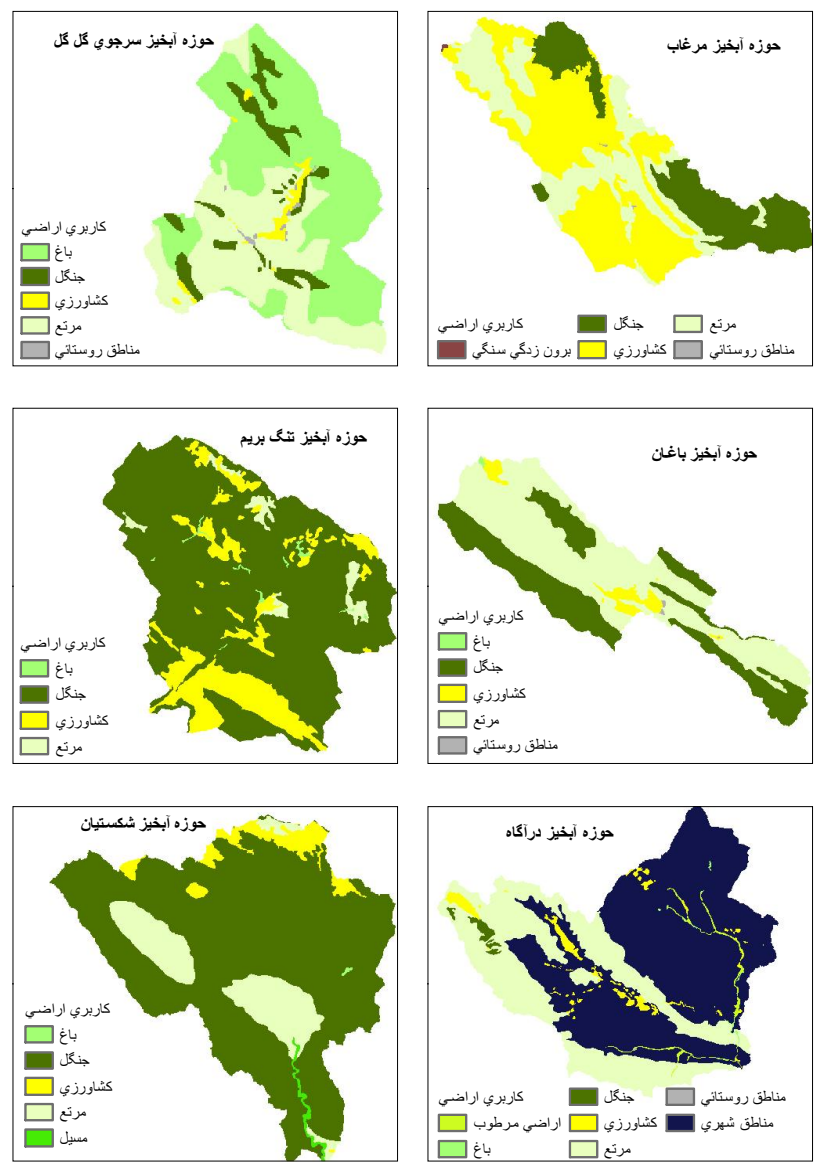

شكل r. نقشه كاربرى اراضى در حوضههاى مورد مطالعه

حاصل از حساسيت سنجى مدل نشان مىدهـــ كـهـ بارامترهـاى ثابت تخليه آب زيرزمينى (ALPHA_BF)، شماره منحنى (CN) و ظرفيت آب قابل دسترس خاى (SOL_AWC) از حساسـيت

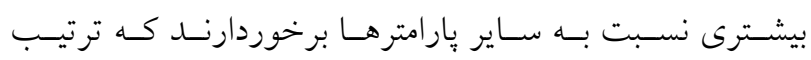

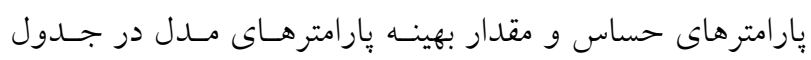
(Y) (Y) نشان داده شده است. براى شبيهسازى س/T دادههاى هيدرومترى مشـاهداتى بــراى

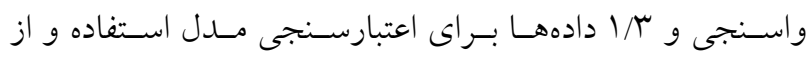
روشهاى آمارى متداول براى ارزيابى دقت مدل در طـول دوره

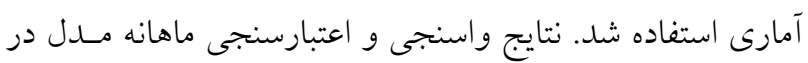
شكل هاى (ه) تا (م () و نتايج شـاخص هـاى ارزيـابى عملكـرد مدل در جدول (r) ارائه شده است. بـهنظـور ارزيـابى اجـــاى صـحيح الخــوريتم ب-SUFI در شبيهسازى جريان رواناب از جهـار عامـل R-factor P-factor، 
جدول r. ترتيب پِار امترهاى حساس و مقدار بهينه يֶار امترهاى مدل

\begin{tabular}{|c|c|c|c|c|c|}
\hline مقدار بهينه & 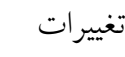 & 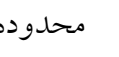 & ترتيب حساسيت & علامت اختصارى & 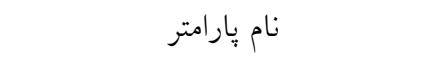 \\
\hline $0 / 09 r$ & $\circ / \circ \vee q$ & $\circ / 09 V$ & 1 & v_ALPHA_BF.gw & ثابت تخليه آب زيرزمينى \\
\hline$-0 /$ TA & $-0 /$ TYq & $-0 / Y T V$ & r & r_CNY.mgt & شماره منحنى روش SCS \\
\hline$-0 / r V \mu$ & $-0 / \pi 10$ & $-0 / Y I V$ & r & r_SOL_AWC(1).sol & ظرفيت آب قابل دسترس خاك \\
\hline$T / 01 T$ & $|/ V+|$ & $r / 0 T^{2}$ & r & r__SOL_Z(1).sol & عمق خاى \\
\hline$V / \Delta \Delta V$ & $4 / 9 \circ 0$ & $14 / \pi \Delta$ & $\Delta$ & v_GWqmn.gw & حداقل ذخيره آب زيرزمينى براى رخ \\
\hline$-0 / 0 \mathrm{HV}$ & $-0 / 0 V \mu$ & $-0 / 0 Y \Delta$ & 4 & v_ESCO.hru & فاكتور جبران تبخير در خاك \\
\hline -/DQY & $0 / 4 y \mid$ & $0 / 9 Y \mid$ & $\checkmark$ & v_REVAPMN.gw & آستانه تراز آب در سفره سطحى براى \\
\hline$-\circ / 9 \circ V$ & $-\circ / 9 \circ V$ & $-0 / 199$ & $\wedge$ & r_gw_revap.gw & ضريب تبخير از سفره زيرزمينى \\
\hline MV/TOA & $r G / 4 \circ 4$ & rV/TVI & 9 & v_GW_DELAY.gw & زمان تأخير آب زيرزمينى \\
\hline $11 / \mathrm{VA}$ & $11 /$ res & $|Y / Y|$ & 10 & $\mathrm{v} \_$CH_KY.rte & هدايت هيدروليكى كانال \\
\hline
\end{tabular}

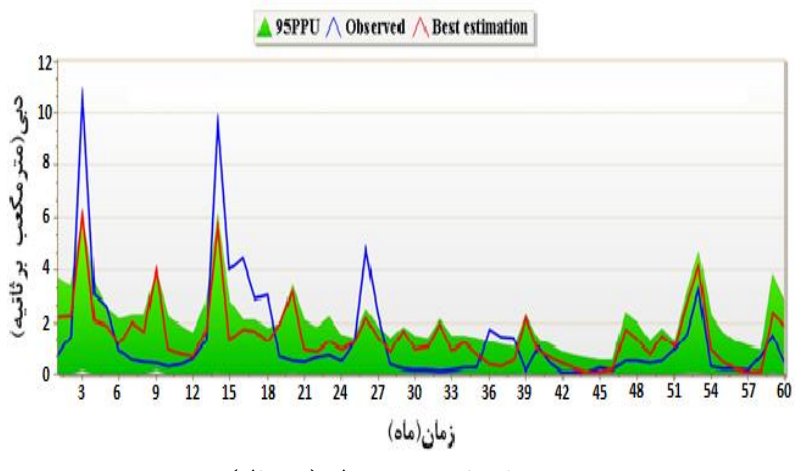

دوره اعتبارسنجى مدل (^ سال)

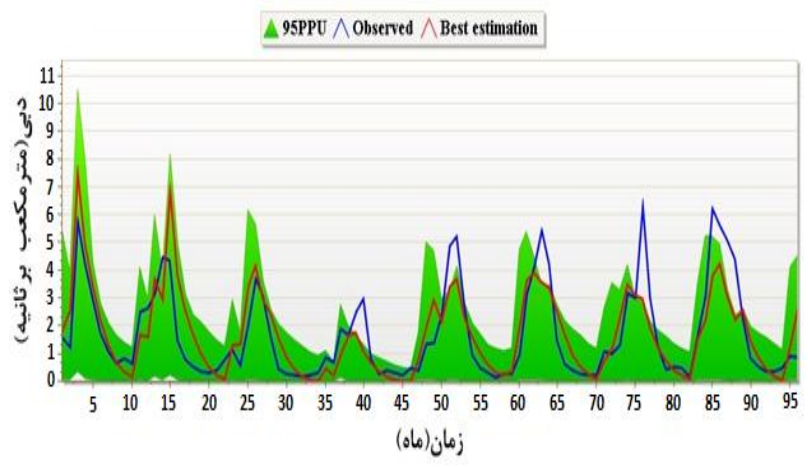

دوره اعتبارسنجى مدل (ه سال)

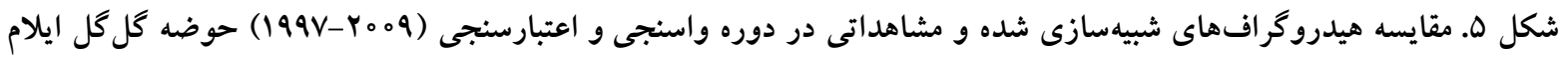

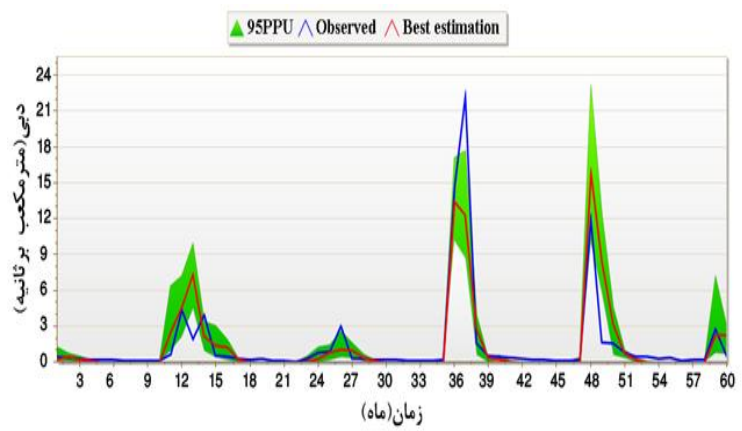

دوره اعتبارسنجى مدل (ه سال)

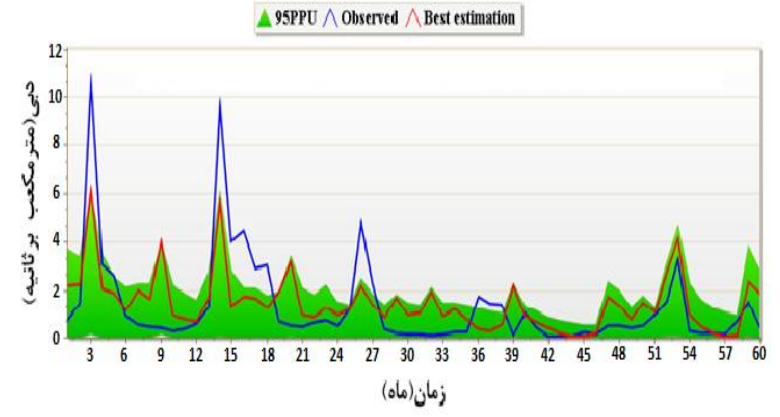

دوره اعتبارسنجى مدل (r سال)

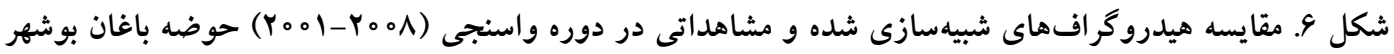




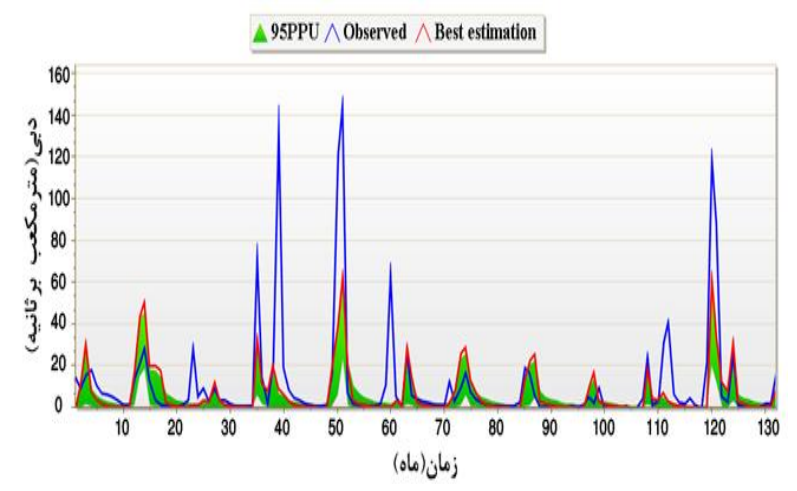

دوره اعتبارسنجى مدل (^ سال)

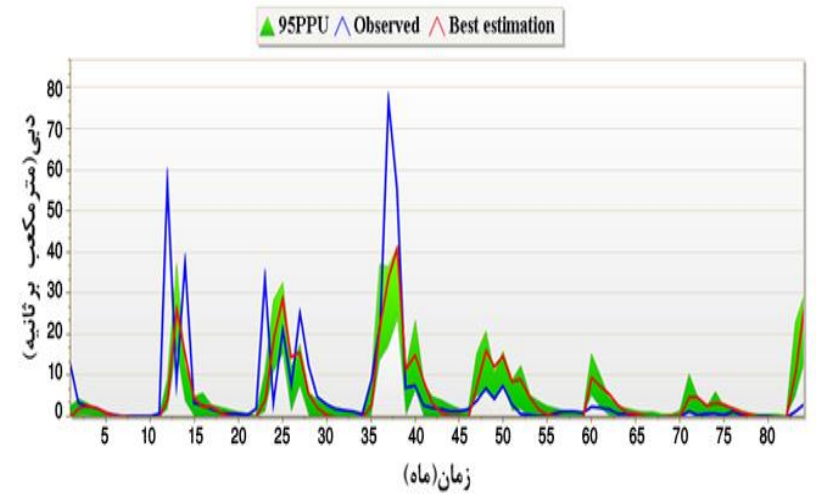

دوره اعتبارسنجى مدل (V) سان)

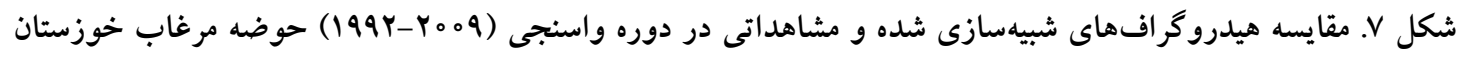

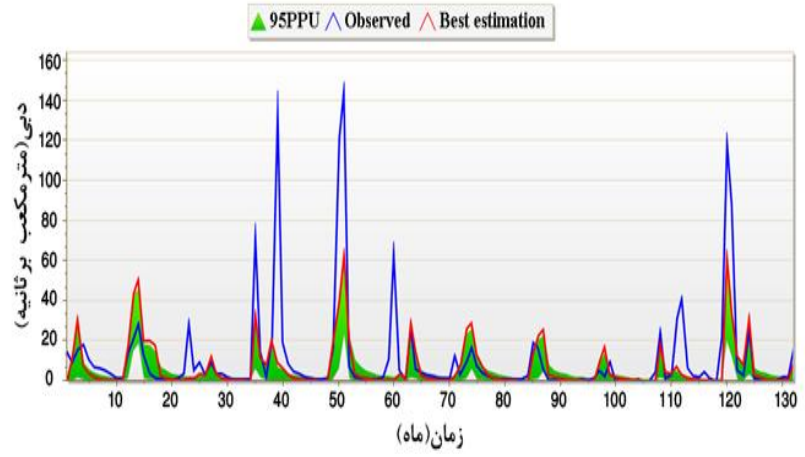

دوره اعتبارسنجى مدل (11 سانطال)

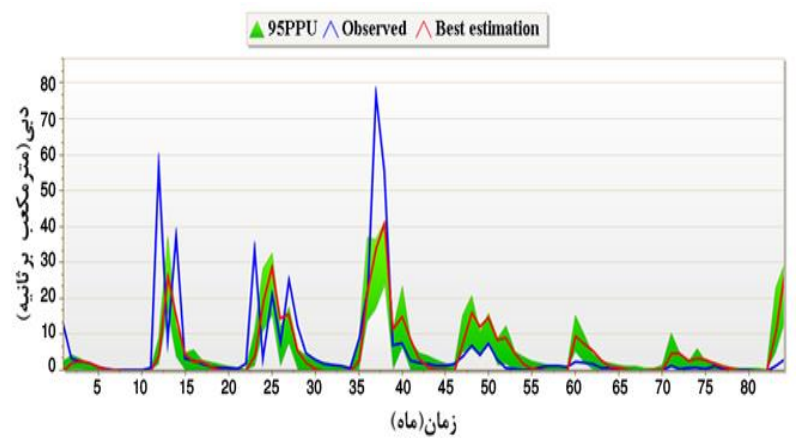

دوره اعتبارسنجى مدل (V) سال)

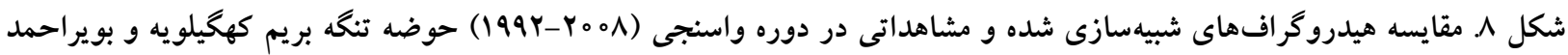

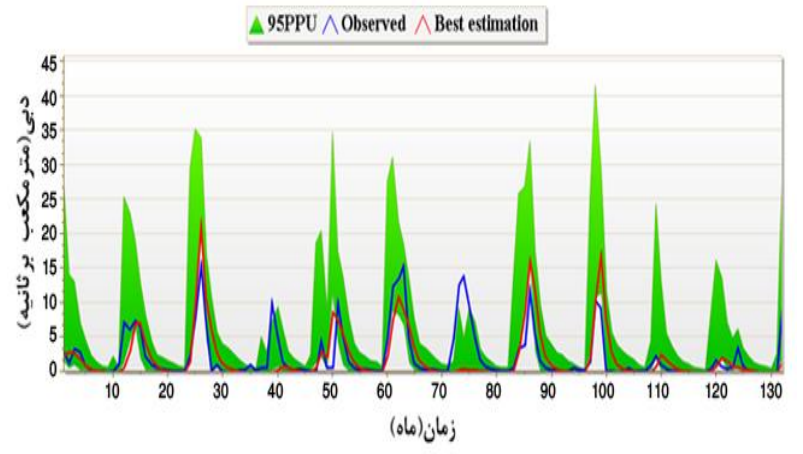

دوره اعتبارسنجى مدل (11 سال)

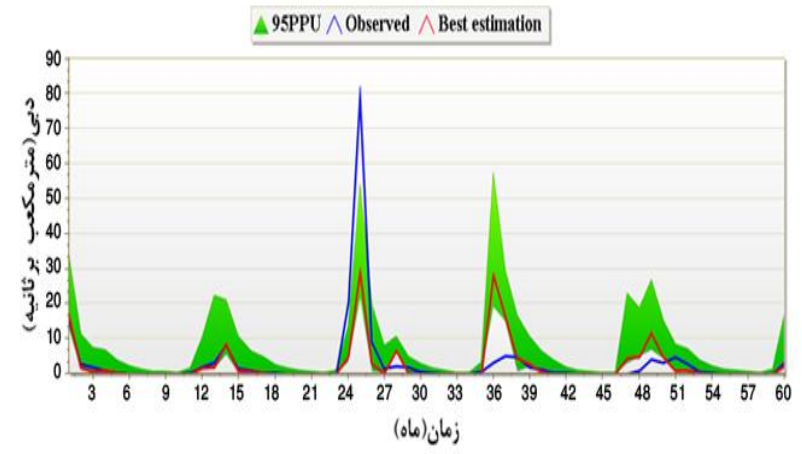

دوره اعتبارسنجى مدل (ه سال)

شكل 9.

براى اين فاكتور به عدد صفر نزديكتر باشد، نشاندهنده تطـابق

بهتـر دادههـاى شـبيهسـازى شــده بــا دادههــاى مشـاهداتى يــا

اندازه گيرى شده است، اما به خاطر داشته باشيم كه مقادير بهينـه
(PPU9D) عدم قطعيت، كمترين ضخامت را داشته باشد. محسدوده فـاكتور

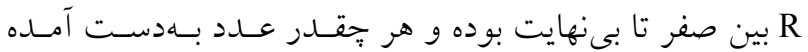




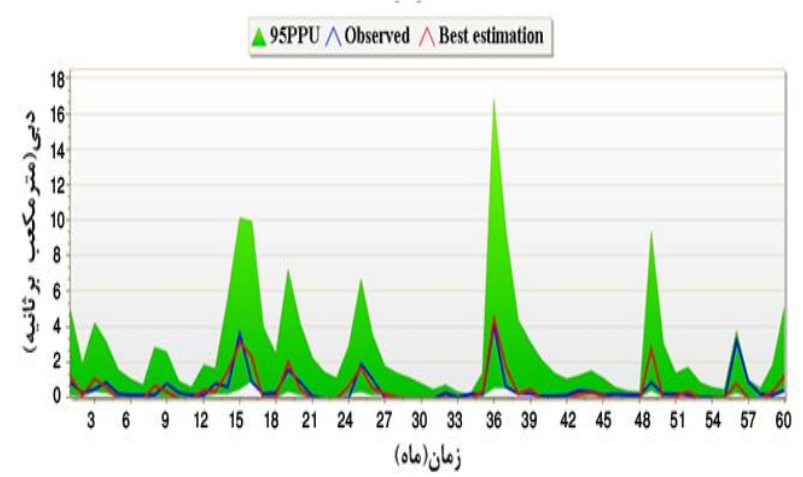

دوره اعتبارسنجى مدل (11 سال)

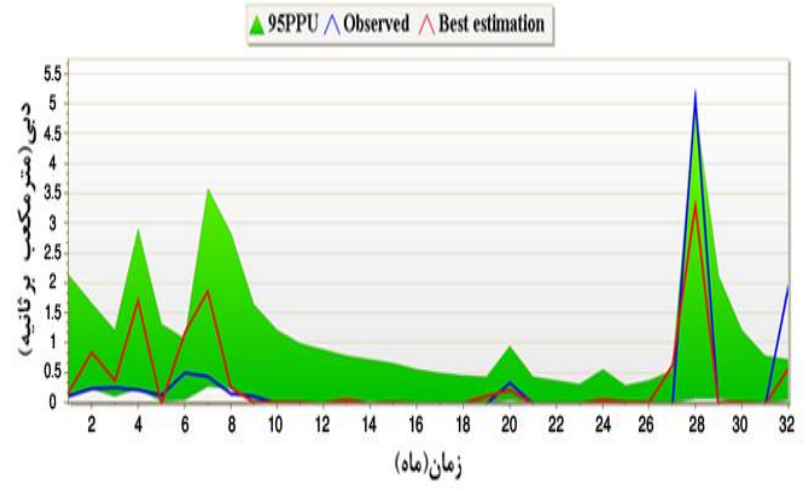

دوره اعتبارسنجى مدل (ه سال)

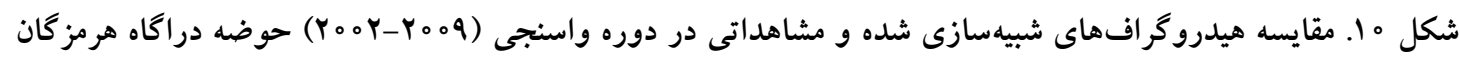

جدول r. ارزيابى عملكرد مدل و نتايج حاصل از واسنجى و اعتبارسنجى در حوضههاى مورد مطالعه

\begin{tabular}{|c|c|c|c|c|c|c|c|}
\hline 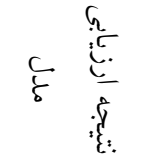 & Z & $\sigma_{1}$ & $\begin{array}{l}\vec{v} \\
1 \\
\overrightarrow{0} \\
\stackrel{0}{0} \\
0\end{array}$ & $\begin{array}{l}0 \\
1 \\
\vec{\approx} \\
0 \\
0\end{array}$ & $\xi$ & $\stackrel{\circ}{6}$ & نام حوضه \\
\hline رضايتبخش & $0 / 94$ & $0 / 94$ &.$/ 90$ & $\circ / r^{\mu}$ & $\wedge$ & واسنجى & \multirow{2}{*}{ كل كل_ ايلام } \\
\hline رضايتبخش & $0 / 4 q$ &.$/ 01$ & O/AY & $1 / 0 \mu$ & 0 & اعتبارسنجى & \\
\hline رضايتبخش & $\circ / \varphi_{0}$ & $\circ / 4 Q$ & $\circ / 0 \Lambda$ & $\circ / T V$ & 11 & واسنجى & \multirow{2}{*}{ مرغاب ـ خوزستان } \\
\hline رضايتبخش & $\circ / 4 \circ$ & $0 / 41$ & $0 / 9 \mathrm{~V}$ & $\circ / 4 \circ$ & v & اعتبارسنجى & \\
\hline رضايتبخش & $\circ / \varphi_{0}$ & $0 / 140$ & $\circ / \Delta \Lambda$ & $\circ / T V$ & 11 & واسنجى & \multirow{2}{*}{ تنخ بريم ـ كهخيلويه و بوير احمد } \\
\hline رضايتبخش & $\circ / 4 \circ$ & $0 / 41$ & $0 / 9 \mathrm{~V}$ & $\circ / 4 \circ$ & 9 & اعتبارسنجى & \\
\hline غير قابلقبول & O/r & $0 /$ MY & $\circ / \Lambda \Lambda$ & $1 / 9 \Lambda$ & 11 & واسنجى & \multirow{2}{*}{ شكستيان _ فارس } \\
\hline رضايتبخش & $0 / 40$ & $0 / 49$ & $\circ / \wedge \Delta$ & $0 / 49$ & 0 & اعتبارسنجى & \\
\hline رضايتبخش & $\circ / N$ & $\circ / V 4$ & $\circ / N \Delta$ & $\circ / \mu q$ & 0 & واسنجى & \multirow{2}{*}{ باغان - بوشهر } \\
\hline رضايتبخش & $\circ / \uparrow \wedge$ & $0 / 9 \mathrm{~V}$ & $\circ / 0 \circ$ & $r / Y q$ & $r$ & اعتبارسنجى & \\
\hline عالى & $\circ / \mathrm{VA}$ & o/AY & $0 / 9 \mathrm{~V}$ & ०/Or & 0 & واسنجى & \multirow{2}{*}{ دراكاه _ هرمز كان } \\
\hline رضايتبخش & $0 / 94$ & $0 / 94$ & $0 / \mu$ & I/T & $r$ & اعتبارسنجى & \\
\hline
\end{tabular}

براى بارامترهاى مدل در هنخام شـبيهسـازى از تناسـب مقـادير رضايت بخش بودن نتايج در كليه حوضهها بجز دوره واسـنجى

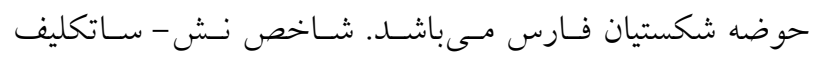

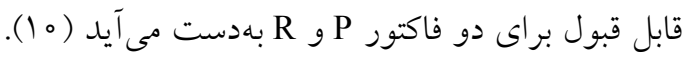

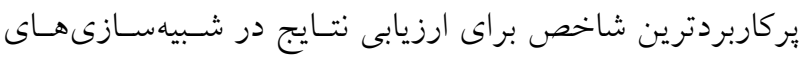

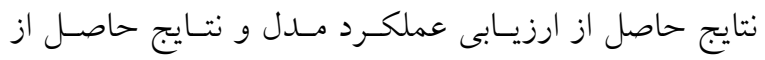

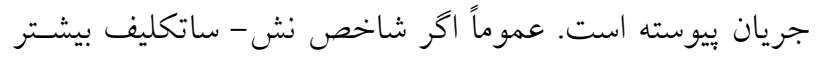
واسـنجى و اعتبارسـنجى در حوضـهـــاى مـورد مطالعـه نشـان

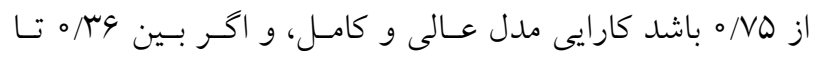

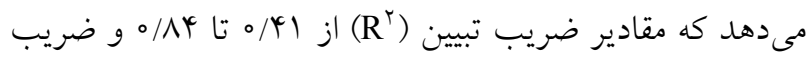

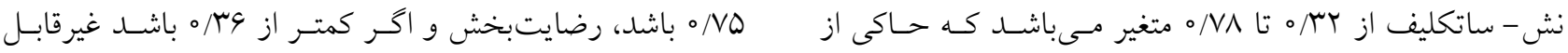


جدول أ. حجم آب قابل استحصال در حوضههاى شش كانه مورد مطالعه

\begin{tabular}{|c|c|c|c|c|c|c|}
\hline 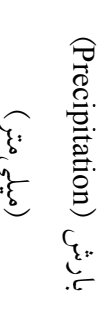 & 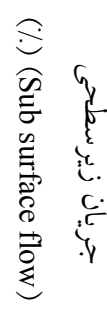 & 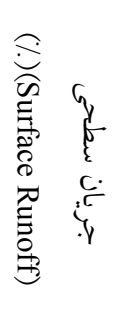 & 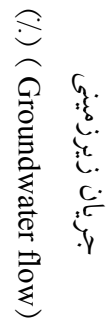 & 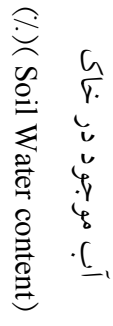 & 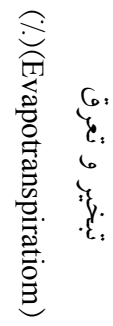 & حوضه \\
\hline$D \circ Y$ & $\wedge$ & 10 & V & r & VT & كل گل ايلام \\
\hline 949 & 1 & at & 9 & $r$ & 49 & مرغاب خوزستان \\
\hline$\vee \circ \Lambda$ & $r$ & M & 9 & 1 & $\Delta \Delta$ & تنخ بريم كهخيلويه \\
\hline 010 & ir & 0 & $r$ & r & Ve & شكستيان فارس \\
\hline 119 & 1 & 19 & r & r & $v^{q}$ & باغان بوشهر \\
\hline 90 & r & $\circ / 4$ & $0 / 01$ & $0 / 09$ & 99 & درآ كاه هرمز كان \\
\hline
\end{tabular}

از طريق به دام افتادن در جّالاب تبخيـر مسىشـود و يـا بـس از جارى شدن به دريا ريخته و فرآيند تبخير در آن شكل مى گيرد. ارزيابى جريان سطحى نشان مىدهد كه حوضههاى مرغـاب

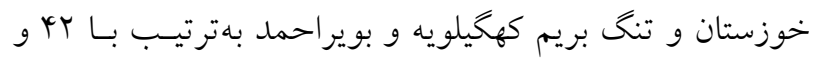
اس درصد بيشترين جريان سطحى را بهخود اختصاص مىدهنـد كه برنامه ريزان محلى را بر اين وا مىدارد كه از هدررفت جنين سرمايههاى ملى با روشهاى متداول همجيجون بِخش سـيلاب در مخروط افكنهها و ميان دشتهاى حوضه اقدامات اساسى جــاره

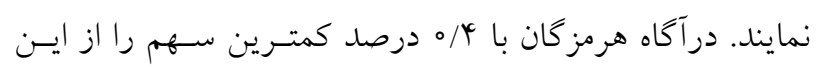
مؤلفه دارا مىباشد. ارزيابى جريان زيرسطحى كه از اهميت ويـزّهاى در مبحسث

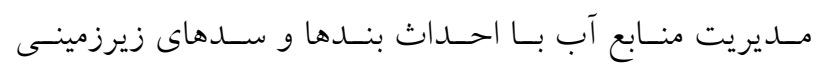
برخوردار است، حاكى از ايناست كـه حوضـههـاى شكسـتيان فارس و كل گل ايلام با بهترتيب سا و 1 درصد بيشـرين سـهم اين مؤلفـه را دارا هسـتند و در صـورت داشـتن سـاير شـرايط

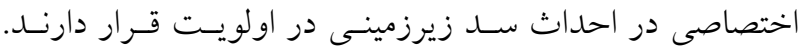
حوضه باغان بوشهر بهدليل وجود بافت سنگين خاك، از حداقل جريان زير سطحى برخوردار است. نتايج اين تحقيق نشان داد كه در كليه زيرحوزههـا تبخيــر و

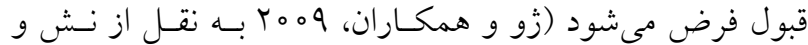
ساتكليف) (11).

بحث و نتيجه كيرى حجم آب قابل استحصال از مؤلفههاى جريان نشان مىدهد كـــ بيشترين سهم بيلان آب مربوط به تبخير و تعرق واقعى مىباشد

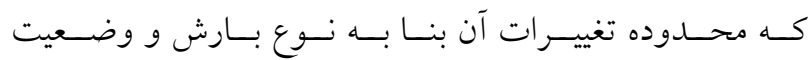
مورفولوزيكى و تويوكرافى منطقه مـورد تحقيـق از در صــ در حوضه مرغاب خوزستان و4 تـا وه درصسد در حوضـه درآكـاه استان هرمز كان متغير است. با توجه به اين درصــ قابـل توجـهـ تبخير و تعرق، برنامهريزى در تغيير الخوى كشـت و اسـتفاده از روشهاى كاهش تبخير رطوبت از سـطح خـاى از ضـروريات

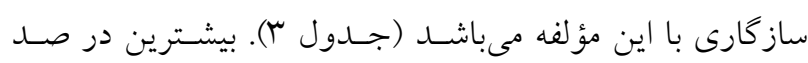
جريان زير زمينى مربوط به حوضههاى مرغاب استان خوزستسان و تنخ بريم استان كهخيلويه و بويراحمد با 9 در صد مىباشد و

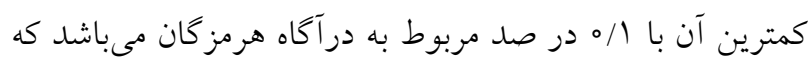

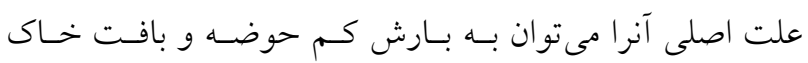
سنخين حوضه نسبت داد. در اين حوضه بهدليـل خــاك شــيداً غير قابل نفوذ، عمده نزولات آسمانى با كمترين نفـوذ در خـاك 


$$
\begin{aligned}
& \text { تعرق واقعى از و4 تا و9 در صد، جريان زيرزمينى از r تـا } 9 \text { در تأثير قرار داده و بهرهبرداران و تصميم گير ان محلى و منطقهاى را } \\
& \text { صد، جريان سطحى از †/ه تا بأ در صد و جريان زير سـطى در مديريت اين عوامل كوشا سازد. } \\
& \text { بنابراين مىتوان در يكى نتيجه كيرى كلى به توانايى و كارايى } \\
& \text { از ا تا سا در صد متغير است. حسينى و اشرف (N) در تحقيـق } \\
& \text { مدل فيزيكى SWAT در حوضه هاى منتهى به مرزهاى جنوب و } \\
& \text { خود در حوزه آبخيز طالقان نشان دادند كه مقادير اين مؤلفـهــا }
\end{aligned}
$$

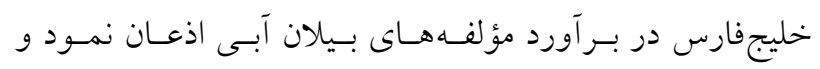

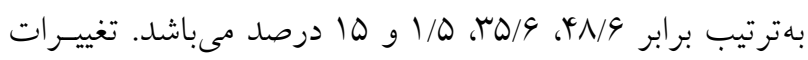

$$
\begin{aligned}
& \text { برنامهريزان محلى و منطقهاى را در زمينه استفاده از بتانسيل هاى } \\
& \text { منابع آب موجود در منطقه ييش آكاهى داد. }
\end{aligned}
$$

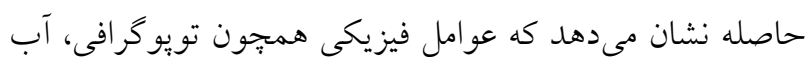

$$
\begin{aligned}
& \text { و هوا، خاك و كاربرى اراضى مىتواند مؤلفهاى بيلان را تحت }
\end{aligned}
$$

\section{منابع مورد استفاده}

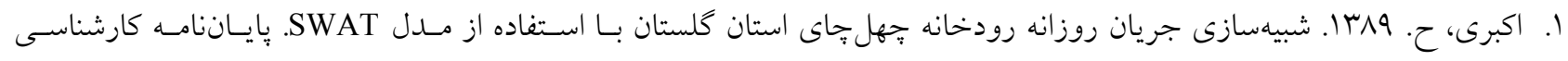

$$
\text { ارشددانشكده كشاورزى و منابع طبيعى گرگان. }
$$

r. حسينى، م.، م. ر. طباطبايى، ا. سررشته دارى، س. ع. خلخالى، م. گودرزى. rar ا. كزارش نهايى طرح تحقيقاتى شبيهسازى بـبلان

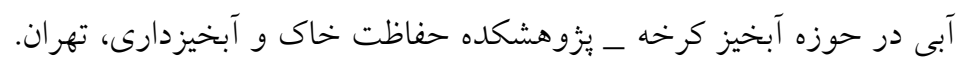

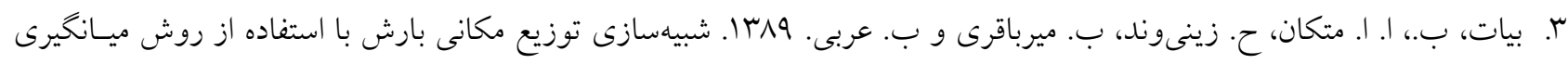
در محيط GIS (مطالعه موردى: حوضه مركزى كرمانشاه). مجموعه مقالات اولين كنفرانس بينالمللى مدلسازى كياه، آب، خـاك

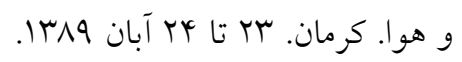

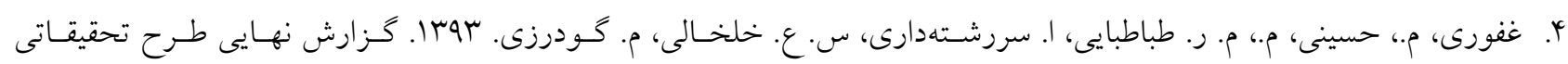

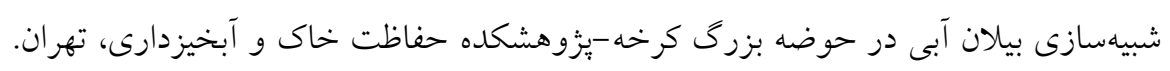

5. Arnold, J. G., R. Srinivasan, R. S. Muttiah, J. R. Williams. 1998. Large area hydrologic modeling and assessment part I: model development. J. of the Am. Water Resour. Association 34(1): 73-89.

6. Abbaspour, K. C. 2008. SWAT-CUP2: SWAT Calibration and uncertainty programs-A user manual. department of systems analysis, Integrated Assessment and Modeling (SIAM). Eawag, Swiss Federal Institute of Aquatic Science and Technology, Duebendorf, Switzerland.

7. Abbaspour, K. C., A. Johnson Van and M. Th. Genuchten. 2004. Estimating uncertain flow and transport parameters using a sequential uncertainty fitting procedure. Vadose Zone J. 3(4): 1340-1352.

8. Hosseini, M. and M. A. Ashraf. 2015. Application of the SWAT model for water components separation in Iran. Springer, Japan. PP: 97-98.

9. Hosseini, M., 2010. PhD Thesis., Effect of landuse changes on surface runoff and suspended sediment yield of Taleghan catchment, Iran. UPM. PP: 10-57.

10. Narsimlu, B., A. K. Gosain, B. R. Chahar, S. K. Singh and P. K. Srivastava. 2015. SWAT model calibration and uncertainty analysis for streamflow prediction in the Kunwari river basin, India, using sequential uncertainty fitting. Environ. Processes 2: 79-95.

11. Nash, J. E., J. V. Sutcliffe. 1970. River flow forecasting through conceptual models 1.A Disscussion of principales. J. of Hydrology 10(3): 282-290.

12. Neitsch, S. L., J. G. Arnold, J. R. Kiniry, R. Srinivasan, J. R. Williams. 2005. Soil and Water Assessment Tool (SWAT), Theoretical Documentation: Version 2005". USDA Agricultural Research Service and Texas A\&M Blackland Research Center,Temple.

13. Rostamian, R., A. Jaleh, M. Afyuni, S. F. Mousavi, M. Heidarpour, A. Jalalian, K. Abbaspour. 2008. Application of a SWAT model for estimating runoff and sediment in two mountainous basins in central Iran, Hydrological Sci. 53: 977-988.

14. Yang, J., K.C. Abbaspour and P. Reichert H. Yang. 2008. Comparing uncertainty analysis techniques for a SWAT application to Chaohe basin in China. J. Hydrology 358(1-2):1-23. 


\title{
Estimation of Water Balance in watersheds led to west-south frontiers and Persian Gulf by Semi Distributed SWAT Model
}

\author{
M. Hosseini ${ }^{* 1}$, M. Ghafouri ${ }^{1}$, Z. Mokarian ${ }^{1}$ and M. R. Tabatabaei ${ }^{1}$
}

(Received: March 14-2015 ; Accepted: Oct. 1-2016)

DOI: $10.18869 /$ acadpub.jstnar.20.78.183

\begin{abstract}
In the last decades, climate change and fluctuation of water balance have been the main reason to apply hydrologic models for estimating quality and quantity of water components as efficient tools in water planning of critical conditions. In addition, these hydrologic models with potential to study the effects of watershed management practices on the runoff components are suitable tools for optimization of watershed operations at present and future. In this research Soil and Water Assessment Tools (SWAT) model has been applied to estimate groundwater runoff for 6 provinces such as Eilam (Golgol Catchment), Boushehr (Baghan Catchment), Khozestan (Morghab Catchment), Fars (Shekastian Catchment), Kohkiloyeh \& Boyer Ahmad(Tange Birim Catchment) and Hormozgan (Daragah Catchment) which are located in south and south west of Iran. In order to evaluate the performance of the model, hydrological data, soil, land use and Digital Elevation Model (DEM) entered for each catchment to run the SWAT model. SWAT-CUP with SUFI2 program was used for simulation, uncertainty and validation with 95ppu. P-factor and R-factor are two internal evaluation factors in SUFI2 program and indicators such as the coefficient of determination $\left(\mathrm{R}^{2}\right)$ and NashSutcliffe (NS) were used for evaluation of the model. The Nash-Sutcliffe coefficients in six mentioned catchments for calibration period are $0.66,0.73,0.40,0.32,0.53$ and 0.78 . They are $0.49,0.48,0.42,0.45,0.46$ and 0.62 for validation period, respectively. Model calibration and validation results showed good performance in estimating the water balance of the basins studied. Except for Shecastian catchment, the evaluation results showed acceptable and favorable results for water balance in the study area.
\end{abstract}

Keywords: Persian Gulf, South Watersheds, SWAT, Water Balance.

1. Soil Conservation and Watershed Management Research Institute, Agricultural Research, Education and Extension Organization (AREEO), Tehran, Iran

*: Corresponding Author, Email: mjhossaini@yahoo.com 